28 : 383-408, 1948. 4) Danneel, R. und Cleffmann, G. : Die Einwanderung der Pigmentzellen in die Haut und die Haare bei Nagetieren. Biol. Zentralbl., 73:414-428, 1954. 5) Zimmermann, A. A. : Die Entwicklung der Hautfarbe beim Neger vor der Geburt. Mitteilungen d. Thurg. Naturforsch. Gesellschaft Switzerland; Heft $37: 33-71,1954$. 6) Danneel, R. und Weissenfels, N. : Die Herkunft der Melanoblasten in den Haaren des Menschen und ihr Verbleib beim Haarwechsel. Biol. Zentralbl., 72:630-643, 1953. 7) Zimmermann, A. A. and Cornbleet, Th. : The development of epidermal pigmentation in the Negro fetus. J. Invest. Dermat., $11: 383-392,1948 . \quad 8)$ Zimmermann, A. A. : The development of epidermal pigmentation in the Negro fetus. Zoologica, $35: 10-12,1950.9$ 9) Becker Jr., S. W. and Zimmermann, A. A. : Further studies on melanocytes and melanogenesis in the human fetus and new-born. J. Invest. Dermat., $25: 103-112,1955 . \quad 10)$ Zimmermann, A. A. and Becker Jr., S. W. : Precursors of epidermal melanocytes in the Negro fetus, in Pigment Cell Biology, ed. by Gordon, Academic Press Inc., New York, 1959. Pages 159-170. 11) Szabo, G : Quantitative histochemical investigations on the melanocyte system of the human epidermis. Ibid. Pages 99-125. 12) Dry, F. W. : The coat of the mouse (Mus musculus). J. Genet. $16: 287-340$, 1926. 13) Chase, H. B., Rauch, H. and Smith, V. W. : Critical stages of hair development and pigmentation in the mouse. Physiol. Zool., $24: 1-8,1951$. 14) Pearse, A. G. E. : Histochemistry, Theoretical and Applied. J. and A. Churchill, Ltd., London, 1960. Pages 524, 905 and 919. 15) Becker Jr., S. W., Praver, L. L., and Thatcher, H. : An improved (paraffin section) method for the DOPA reaction, with considerations of the DOPA-positive cell, as studied by this method. Arch. Derm. and Syph., $31: 190-195,1935.16)$ Zimmermann, A. A.: in the discussion of "Melanocyte system of human epidermis", in Pigment Cell Biology, ed. by M. Gordon, Academic Press Inc., New York, 1959. Page 125. 17) Adachi, B : Hautpigment beim Menschen und bei den Affen. Z. Morphol. u. Anthropol. 6 : 1-131, 1903. 18) Birbeck, M. S. C. and Barnicot, N. A. : Electron microscope studies on pigment formation in human hair follicles, in Pigment Cell Biology, ed. by M. Gordon, Academic Press Inc., New York, 1959. Pages 549-561. 19) Fitzpatrick, T. B., Brunet, P. and Kukita, A. : "The nature of hair pigment", in the Biology of Hair Growth, ed. by W. Montagna and R. A. Ellis, Academic Press Inc., New York, 1958. Pages 255-303. 20) Chase, H. B. : "Behavior of pigment cells and epidermal cells". Ibid. Pages 229-237.

\title{
Histochemistry of Protein Groups
}

\section{A Significance of Alloxan-and Ninhydrin-Schiff Methods for Protein}

\author{
Yasuo DEGUCHI \\ Department of Oral Surgery, Osaka University Dental School, Osaka.
}

\section{Introduction}

The alloxan-and ninhydrin-Schiff methods have been accepted to be the most specific and available reactions in protein histochemistry. ${ }^{1-4)}$ The millon reaction $^{5)}$, the dinitrofluorobenzene $\mathrm{H}$-acid method, ${ }^{4,6)}$ the coupled tetrazonium $\operatorname{method}^{7)}$ and the dimethylaminobenzaldehyde reaction for tryptophane ${ }^{8,9)}$ are also being employed in histochemical detections of proteins, elastic and kollagen fibers, amyloid, ${ }^{10-12)}$ etc. 
The results in the present study indicate that comparatively similar findings are observed in the determination of proteins in tissue sections with the above methods except for the dimethylaminobenzaldehyde reaction, and that the content of amino acid in tissue protein cannot always be estimated by these methods. ${ }^{13)}$

The main purpose of this work was to confirm the specifity of the alloxanand ninhydrin-Schiff methods for protein groups, and to clarify the possible effects of some histochemical fixatives on protein in reference to digesting effects of crystalline pepsin and trypsin, and also to study the changes of the stainability after blocking of terminal amino groups with nitric acid and anhydrous acetic acid etc.

\section{Meterials and Methods}

The tissues including the rat liver, kidney, pancreas, salivary glands, oral mucosae, stomach and small intestine were prepared for cold microtome sections at the thickness of $8 \mu$ or $16 \mu$. For the histochemical demonstration of tissue protein, the raw-frozen sections were believed to be very useful to preserve it in relatively natural conditions without being affected by fixation or embedding. Some materials were fixed in absolute acetone or in $10 \%$ formalin, then embbeded in paraffin.

Fresh frozen sections dried in room temperature, fixed in acetone, absolute ethanol and methanol, $10 \%$ formalin, Zenker's solution, Bouin's solution, or trichloracetic acid alcohol for 15 minutes, were employed in the following method.

Alloxan- and Ninhydrin-Schiff Methods ${ }^{1)}$ : The fixed sections were treated with 1.6 alloxan or $0.5 \%$ ninhydrin in absolute ethanol for $2-3$ hours at $37^{\circ} \mathrm{C}$. Ninhydrin and alloxan produce Schiff base by oxidative deamination of amino groups. Alloxan were very soluble in water more than in ethanol, but no color developed in water solution. The sections were rinsed in absolute ethanol and water untill completely discolored, and were immersed in Schiff's reagent for 30 minutes, then immediately rinsed in three changes of $10 \%$ sodium bisulfide solution, and washed in running water. After dehydration the sections were mounted with balsam.

Millon Reaction : Millon's solution ${ }^{5)}$ was prepared according to Gersh and Bensley's modified method. Non-fixed sections after dried in room temperature were treated with Millon's solution for $3-5$ hours at $37^{\circ} \mathrm{C}$. A brownish color developed at the positive portion. Then they were washed in $1 \%$ nitric acid and in water. Glycerol mounting preserved in reaction for several months.

\section{Observation}

Liver : The cytoplasm of hepatic cells was well stained diffusely, indicating the presence of protein substance in great amount. Paraffin sections showed a more granular reaction than in frozen sections. Granular reaction was recognized in the intercellular space. Similar staining reaction were observed 
between the central and peripheral parts of hepatic lobules. The nuclei were moderately reactive in the formalin fixed tissues, while they were more intensely stained than the cytoplasm in the paraffin sections.

Kidney : Epithelial cells of the distal and medial convolutions were stained markedly by alloxan Schiff and Millon's reactions. Erythrocytes in the glomerulus and tubules were also stained pink with the alloxan-Schiff method. The cortex of the kidney showed a strong stainability.

Pancreas: The cytoplasm of pancreatic acinar cells was strongly reactive, and the cells of Langhans islets were weaker. Sometimes, some pancreatic acini were stained more intensely than the other cells subjected to the DMABnitrite reaction. It was assumed that those findings might be related with the production of proteolytic pre-enzymes, trypsinogen and chymotrypsinogen in the pancreatic acini.

Salivary gland: In the submandibular gland, the serous cell was moderately reactive and the duct cell strongly reactive. Nuclear staining of the acinar and duct cells was moderate in the formalin fixed sections and less in the acetone fixed ones. The mucous acini were scarcely reactive. The mucous acini of the sublingual gland were not or slightly reactive as the mucoid cells in the submandibular gland. The basal portions of the acinar and demilune cells were stained moderately, and the duct cells showed a good stainability. Mucous cells were not stained by the alloxan-Schiff and Millon reactions. Parotid gland; Both the acini and duct cells showed a more intense reaction than that of the serous acini of the submandibular gland. The stainability was similar to that in the cytoplasm of the pancreas.

Stomach: The gastric epithelium was generally moderately stainable and the chief cells of the gastric gland stained more intensely. The muscular zone of the stomach showed also a strong stainability.

Intestines: The intestinal epithelium was moderately stained, but the mucous intestinal gland in the duodenum and bowels showed a negative reaction.

\section{Blocking Test}

The blocking of protein end groups by chemical agents is well sufficient and simple for demonstrating histochemical specificity, according to Danielli. ${ }^{6}$

Frozen sections fixed in acetone or $10 \%$ formalin were used. Deamination with nitrous acid for 24 hours, acetylation with $30 \%$ acetic anhydride in pyridine were carried out, and also benzoylation with $5 \%$ benzoyl chloride in pyridine and pretreatment with dinitrofluorobenzene in $90 \%$ alcohol with $\mathrm{M} / 100 \mathrm{NaOH}$ were performed. Incubation time was $2 \sim 3$ hours at $37^{\circ} \mathrm{C}$. The other sections fixed with $10 \%$ formalin were immersed in $\mathrm{M} / 10$ monoiode acetic acid, adjusted the $\mathrm{pH}$ to 8 with $\mathrm{N} / 10 \mathrm{NaOH}$, for 20 hours. This agent has been known to block active sulfhydryl groups of protein. ${ }^{14-16)}$

By these pretreatments, the alloxan- and ninhydrin-Schiff reactions were reduced to a slight degree in which the reactions could not be detected macroscopically. But the coupled tetrazonium reactions were not reduced even by a prolonged benzoylation, and nuclear staining became stronger. ${ }^{3,4,17)}$ 


\section{Digestion with Crystalline Pepsin and Trypsin}

Digestion by purified peptic enzymes may be one of the accepted methods for a histochemical detection of protein. ${ }^{4,13)}$ Actions of pepsin and trypsin are suggested by the study of Mazia and Kaufmann et al. on the protein structure of chromosomes. ${ }^{18,19}$ ) They believed that main actions of trypsin were attributable to the digestion of peptic links in basic proteins. Mazia found that pepsin would not digest histones in solution but would digest acidic protein. Kaufmann also believed that the principal action of pepsin is removal of tryptophan containing proteins of the non-histone variety. It is well known that pepsin has a marked digestive effect on native collagen fibers.

Acetone and $10 \%$ formalin fixed paraffin sections of major salivary glands were utilized in this test. A solution containing enzymes was prepared as follows; $10 \mathrm{mg}$ of crystalline pepsin was added to $10 \mathrm{ml}$ of $\mathrm{N} / 10 \mathrm{HCl}$, and $10 \mathrm{mg}$ of phosphate buffer ( $\mathrm{pH}$ 6.8). Deparaffinized sections by xylene were incubated for 30 90 minutes in peptic solution, and 60 120 minutes in tryptic solution.

The finding obtained with a mild peptic and tryptic digestion showed no structural impairment of the sections, and a prolonged digestion caused a structural destruction. By peptic digestion for 90 minutes, the duct cells and submandibular acini virtually loosed its stainability, only the cell membrane and intercellular fibers were stained; so the digesting action of pepsin was higher than that of trypsin. Furthermore, the stainability of the sections became weaker after both digestions.

\section{Discussion}

Alloxan and ninhydrin are known to oxidize $\alpha$-amino groups which are fixed at the terminal portion of protein chains. ${ }^{1,4,13,20-22)}$ In the process of this reaction, free amino acid and low molecular polypeptide may be dissolved when the histochemical method is employed for protein groups. It has been generally considered that the protein groups responsible for these histochemical methods are mostly the terminal amino groups, and that the alloxan-Schiff method demonstrates terminal $\alpha$-amino groups of protein chains; and the coupled tetrazonium method and DNFB-H acid method demonstrate mainly terminal tyrosine or tryptophane. The DMAB-nitrite method is said to detect likewise tryptophane. ${ }^{13,21)}$ But from the results obtained in this study, the kind of amino acid in the protein components could not be defined.

It is an interesting result that the reactivity of tissue sections with the alloxan-Schiff method is closely related with the histochemical fixatives employed. ${ }^{4,23)}$

Table 1. Effects of Reactivity by Fixatives

\begin{tabular}{l|cccccccc} 
& Non-fixed & Acetone & Ethan. & Methan. Formalin & Zenker & Bouin \\
Alloxan-Schiff-R & $H$ & $H$ & $H$ & $+\sim \#$ & + & + & $-\sim \pm$ \\
Millon-R & $H$ & + & + & $-\sim+$ & + & - & -
\end{tabular}




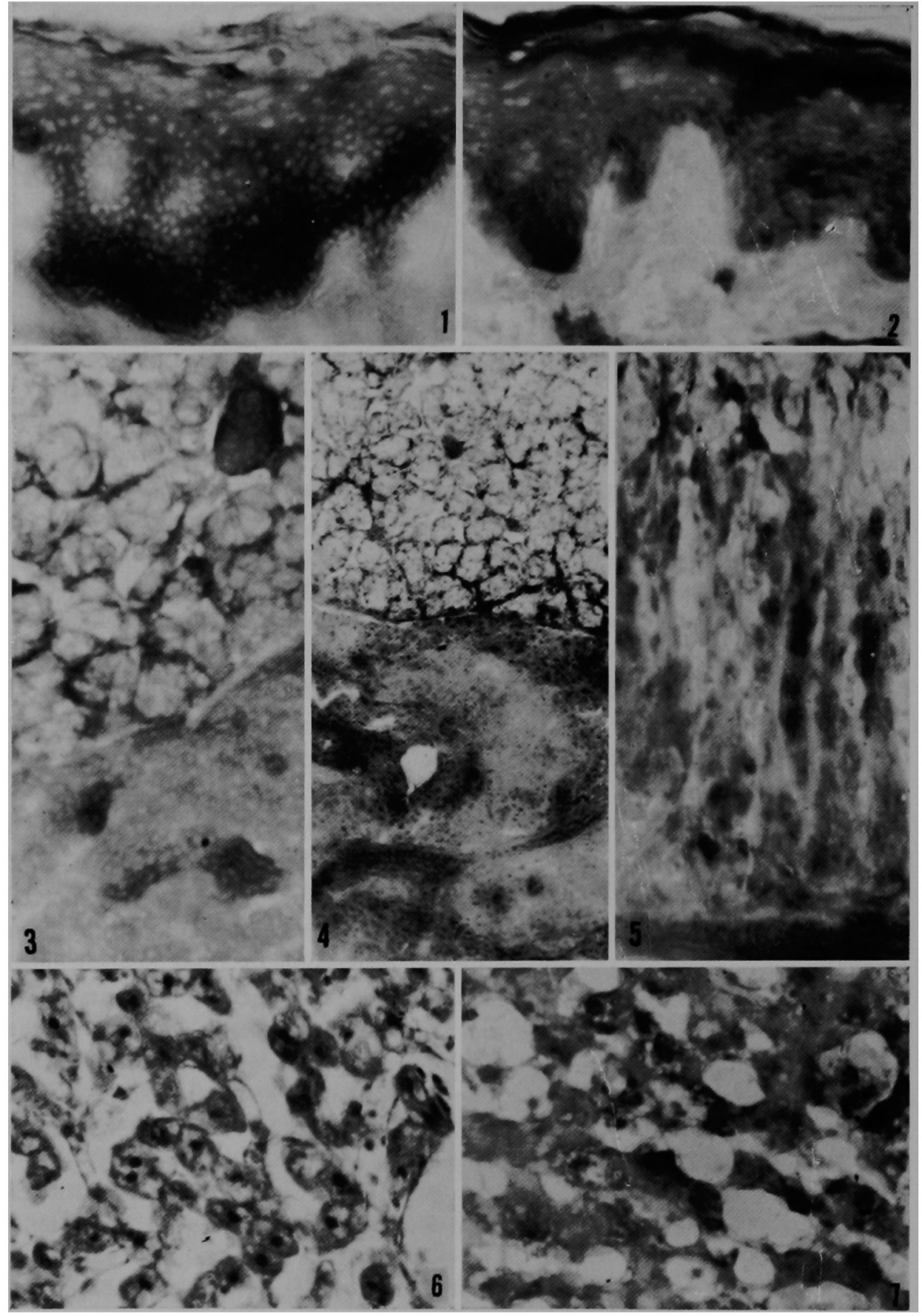

This result will be related with a problem of the fixing mechanism of histochemical fixatives on tissue. But, the chemical and physical actions of fixatives on tissue proteins have not been made clear today. Many authors state that one of the chemical reactions of formaldehyde is the formation of methylene bridge on amino or sulfhydryl groups, and mercurial fixatives 
are combined with acid groups of proteins, especially with hydroxyl and carboxyl groups.

Tissues fixed in $80 \%$ alcohol containg trichloracetic acid showed no difference in their stainability in alloxan-Schiff method comparing with the sections fixed in absolute alcohol, although trichloracetic acid is known to be a strong denaturating agent of protein and to intensify the reaction of protein-bound sulfhydryl groups. ${ }^{(4,16,21)}$

This difference of reactivity between alloxan-Schiff and sulfhydryl reactions after trichloracetic acid fixation may be considered to depend upon the difference in position between amino and sulfhydryl groups in the protein chains.

The results of the blocking test of protein groups and of the digestion by proteolytic enzymes seemed to realize the excellence of the alloxan-Schiff method.

A comparative studies on the reactivity in the histochemical protein mothod and the quantitative estimation of the total protein in tissue is carrying on. The result will be published in another paper.

\section{Summary}

The alloxan- and ninhydrin-Schiff methods for protein groups were studied in reference to their localization in tissue and the availability for the histochemical method with raw-frozen sections.

1) Generally, marked positive reactions were observed in the muscular tissue, elastic and kollagen fibers. From the results obtained in the liver, kidney, pancreas, salivary gland and stomach, a considerable coincidence was observed between the positive reactions of the protein groups and the histochemical distributions of many hydrolytic enzymes which were obtained in the previous studies.

2) In fresh frozen sections, the nuclear reaction were observed after $10 \%$ formalin fixation, whereas no nuclear stain was seen after acetone fixation. Paraffin embedded sections also showed a marked nuclear stainning.

3) By peptic digestion for 90 minutes, the cytoplasma of the duct and acinar cells of the sublingual and parotid glands were scarcely stained, remaining the cell membrane or cell border still stained.

\section{Explanation of Plate}

Fig. 1. Alloxan-Schiff reaction. Acetone fixed oral epithelium. $\times 200$ Nuclear reaction is slight or negative and hornified layer is dissolved a little.

Fig. 2. Alloxan-Schiff reaction. 10\% formalin fixed oral epithelium. $\times 200$ Nucleus is stained more intensely than in Fig. 1.

Fig. 3. Alloxan-Schiff reaction. Acetone fixed sublingual and submandibular salivary gland. $\times 200$

Fig. 4. Sublingual and submandibular gland. Coupled tetrazonium reaction after benzolylation for 2 hours. $\times 100$ Nucleus is stained strikingly.

Fig. 5. Alloxan-Schiff reaction. Formalin fixed stomach epithelium. $\times 400$ 
Fig. 6. Alloxan-Schiff reaction. Liver, formalin fixed, paraffin section. Nuclear stainning is clearly observed. $\times 200$

Fig. 7. Alloxan-Schiff reactions. Liver, formalin fixed, fresh frozen section. $\times 200$

\title{
References
}

1) Yasuma, A. and Ichikawa, T. : Nagoya J. med. sci., 15, 96, 1952.

2) Burstone, M. S. : J. histochem. cy tochem. 3, 32, 1955.

3) Burstone, M. S. : Handbuch der Histochemie, Bd 111 Nucleoprotein. Gustav Fisher Verlag Stuttgart, 244, 1959. 4) Pearse, A. G. E. : London Chirchill, 1960. 5) Bensley, R. R. and Gersh, I. : Anat. Rec., 57, 217, $1933 . \quad 6)$ Danielli, J. F. : Cold Spr. Harb. Symp. quant. Biol., 14, 32, 1950. 7) Bochman, R. and Seitz, H. M. : Histochemie, 2, 307, $1961 . \quad$ 8) Lillie, R. D. : J. histochem. cytochem., 4, 118, 1956. 9) Adams, C. W. M. : J. clin. Pathol., 10, 56, 1957. 10) Weiss, L. D., Tsou, K. and Seligman, A. M. : J. Histochem. Cytochem., 2, 29, 1954. 11) Thompson, S. W., Geil, R. G. and Yamanaka, H. S. : American J. Pathol., 38, 737, 1961. 12) Gössner, W. : Histochemie, 2, 199, 1961. 13) Lison, L. : Histochemie et Cytochimie Animales, Hakusui-sha, Tokyo, 1952 (in Japanese) 14) Barrnett, R. J. : J. Nat. Cancer Inst. 14, 769, 1948.115 ) Kawakatsu, K., Y. Deguchi, R. Oka and Y. Takata, : J, dent. Res., 41, 104, $1962 . \quad 16)$ Hiraide, J. : Progressive study of SH group, Igakuchoin, Tokyo, Japan, $1954 . \quad 17)$ Danielli, J. F. and Barnard, E. A. : Nature, 176, 1450, 1956. 18) Mazia, D., Hayashi, T., and Yodowitch, K. : Cold Spring Harb. Symp. quant. Biol., 12, 122, 1947. 19) Kaufmann, B. P., Gay, H., and McDonald, M. K. : Cold Spr. Harb. Symp. quant. Biol., 14, 85, 1960.20 ) Akahori, S. : Aminosan Oyobi Tanpakushitsu, Kyoritsu-Shuppan Tokyo 1948. 21) Akahori, S. : Koso-kenkyuho, Asakura-Syoten Tokyo 4, 297, 1961. 22) Chu, C. H. U., Fogelson, M. A. and Swinyard, C. A. : J. histochem. cytochem., 1, 392, $1953 . \quad 23)$ Sprung, M. M. : Chem. Rev., 26, 297, 1940.

\section{Histochemical Studies of Amino Groups in Frozen Sections}

\author{
Keisuke Hikima, Akira Kitamura and Takashi Ikeda \\ Department of Pathology, Tuberculosis Research Institute, Kyoto University, \\ Kyoto, Japan (Director: Prof. Hideo TAKAMATSU)
}

Histochemical methods for the demonstration of amino groups have been limited by the small number of specific procedures available, and by the instability of primary amino groups in tissue sections. However, a new reagent, 1,2-naphthoquinone-4-sulfonic acid, has been found to be useful in order to demonstrate the presence of protein-bound amino groups. The tissue sections were deeply colored with the formation of paraquinoid condensation products. These colored products belong to a class of indophenol dyes.

The second method found suitable for the histochemical demonstration of amino groups was the formation of azo dyes. This method is based on the reaction of diazotized amine, produced by incubating a solution of sodium nitrite and hydrochloric acid, with $\beta$-naphthol to form an insoluble colored precipitate 